\title{
Latvijas, Igaunijas un Lietuvas armijas virspavēlnieku un to pārstāvju apspriede Valkā 1920. gada 6. janvārīi
}

\author{
Conference of Commanders-in-Chief of Latvian, Estonian, Lithuanian \\ Armies and Their Representatives in Valka, 6 January 1920
}

\author{
Translation and commentaries by \\ Ëriks Jēkabsons, Dr. hist. \\ Latvijas Universitātes Vēstures un filozofijas fakultātes \\ Vēstures un arheoloǵijas nodalas profesors \\ Aspazijas bulvāris 5, Rīga, LV-1050 \\ E-pasts:eriks.jekabsons@lu.lv
}

Dokumentu publicēšanai sagatavojis, no ang!̣ valodas tulkojis un komentējis

Sarežgīito karu laikā, kad reǵiona valstis cīnījās par savu neatkarību, 1919. gada rudenī ievērojami aktivizējās Baltijas valstu savstarpējās attiecības. Pirmām kārtām to noteica Kārḷa Ulmaņa Latvijas Pagaidu valdības pozīciju nostiprināšanās vasarā, kā arī Pāvela Bermonta (Pavel Bermondt-Avalov) vadītās vāciski krieviskās Rietumkrievijas Brīvprātīgo armijas darbība rudenī, turklāt tieši šo cīṇu laikā dažkārt izpaudās ne vien sadarbība ar otru kopīgo ienaidnieku pēc Sarkanās armijas, bet arī arvien pamanāmākas savstarpējās nesaskaṇas. Savukārt tās lielā mērā noteica gan teritoriālās domstarpības, gan atškirīgā Lietuvas nostāja attieksmē pret Poliju, kas šajā kritiskajā situācijā zināmā mērā bija abu pārējo Baltijas valstu - vispirms Latvijas, taču arī Igaunijas - dabisks sabiedrotais.

Viss minētais izpaudās jau rudenī Tērbatā (Tartu), kur notika Baltijas valstu pārstāvju apspriedes, kuru mērḳis bija panākt ciešāku politisku un militāru sadarbību. Kaut arī decembrī starp Latviju un Lietuvu tika noslēgta vienošanās par militāru kopdarbību pret Bermonta spēkiem gadījumā, ja tie neatstās Lietuvas teritoriju līdz mēneša vidum, tomēr Latvijas mēginājumi īpašās sarunās Kauņā vienoties ar Lietuvu par militāru sadarbību pret Sarkano armiju Latgalē nedeva rezultātu, tādēḷ Rīgā tika panākta slepena vienošanās ar Poliju par kopīgu uzbrukumu Latgalē. ${ }^{2}$ Tas sākās 1920. gada 3. janvārī un ḷoti nepatīkami pārsteidza Lietuvas valdību un armijas virspavēlniecību, jo tādējādi Lietuvas karaspēkam, kas atradās Ilūkstes apriṇḳi, tika atņemta apmēram 20 kilometrus garā fronte pret Sarkano armiju gar Daugavas līniju. Turklāt Latvijas un Lietuvas attiecības palika sarežgìitas arī turpmākajos mēnešos. ${ }^{3}$ 
Līdzīga situācija valdīja arī Latvijas un Igaunijas attiecībās, turklāt galvenais cēlonis tāpat bija meklējams teritoriālajās domstarpībās par Valku un apkārtni, kā arī dažām citām vietām. Un tieši Valkā 1919. gada beigās starp Igaunijas un Latvijas varas iestādēm izraisijās nopietns konflikts, igauniem pat ar brunota spēka lietošanas draudiem mēgeinot panākt latviešu komandantūras un citu Latvijas iestāžu slēgšanu un izraidīšanu no pilsētas. ${ }^{4}$ Vienlaikus Igaunija nepatīkami pārsteidza latviešus, decembra beigās bez brīdinājuma noslēdzot pamieru ar Padomju Krieviju (tas stājās spēkā tieši 3. janvārī, kad sākās latviešu-poḷu karaspēka uzbrukuma operācija Latgalē) un tādējādi dodot iespēju Krievijai pārvietot savas karaspēka daḷas no Igaunijas uz Latvijas frontes sektoru. ${ }^{5}$

Baltijas valstu iekšējā un ārējā situācijā 1919. un 1920. gadā ḷoti nozìmīgu lomu ieņēma sabiedroto misijas, turklāt to teritoriālo nesaskaņu risināšanā sevišķi aktīvi iesaistījās Stīvena Talentsa (Stephen George Tallents) vadìtā Lielbritānijas Politiskā misija un Alfrēda Bērta (Alfred Burt) vadītā Militārā misija, jo britiem l̦oti būtiski bija panākt nesaskaṇu noregulēšanu starp boḷševistiskās Krievijas pretiniekiem. ${ }^{6}$

1919. gada 19. decembrī britu Militārās misijas vadītājs A. Bērts Rīgā pēc samērā plašas iepriekšējas apspriešanās ar Latvijas un Igaunijas virspavēlniecību telegrāfiski vērsās pie Lietuvas armijas virspavēlnieka Prana L Latuka (Pranas Liatukas). Viņš to informēja, ka ir izteicis ideju par regulārām (time to time jeb laiku pa laikam) Igaunijas, Latvijas un Lietuvas armijas virspavēlnieku kopīgām apspriedēm, kurās pārrunātu "militārus, politiskus, robežu, bruñojuma, armijas ekipējuma un sadarbibas pret bol̦ševikiem jautājumus", lai "sasaistitu šis valstis ciešāk kopā savstarpējā atbalstā" un panāktu "labu saprašanos”. Viņš arī atzīmēja, ka gan Johans Laidoners, gan Jānis Balodis "l,oti atbalsta" šādu tikšanās ideju. Piekrišanas gadījumā
A. Bērts telegrammā piedāvāja tikties pirmajā apspriedē 1920. gada 1. janvārī Rīgā. Tomēr 29. decembrī par tikšanās vietu tika izvēlēts abu pušu galvenais strīda objekts Valka, kur sarunas sākās 6. janvārī. ${ }^{7}$

Pielikumā publicētais dokuments, kas sagatavots sarunu iniciatorei - britu misijai - un glabājas Lielbritānijas Nacionālajā arhīvā Londonā Ārlietu ministrijas kolekcijā, detalizēti atspoguḷo svarīgo sarunu norisi, kura līdz šim vēstures literatūrā aplūkota vienīgi vispārīgi un būtībā nepietiekami vai pat kḷūdaini. Piemēram, vēsturnieks Edgars Andersons vien īsi atzīmē, ka 1920. gada 6. janvārī Valkā tikās Latvijas, Igaunijas un Lietuvas armiju virspavēlniecības pārstāvji. Igauniju pārstāvēja J. Laidoners, Lietuvu Antans Merķis, Konstantins Kleščinsks, kā arī militārais padomnieks Frenks Krozjers, bet Latviju - pulkvedis Krišjānis Berķis (neatbilst patiesībai, Latgales divīzijas komandieris K. Berkiis šajā laikā aktīvi gatavojās uzbrukuma sākšanai Latgales frontes kreisajā spārnā - $\bar{E}$. J.), un tika panākta vienošanās par periodiskām sanāksmēm un nepieciešamību vienādot militāro apgādi. ${ }^{8}$ Padomju historiogrāfija aprobežojās ar britu iniciatīvas faktora uzsvēršanu kā pierādījumu viņu imperiālismam un Baltijas valstu atkarībai no britiem, lai saskan,otu ārpolitisko darbību. Kārlis Počs uzsver, ka angḷu virsnieks, kas pavadījis A. Merḳi, piedāvājis nekavējoties noslēgt Baltijas valstu militāro konvenciju. ${ }^{9}$ Arī Lietuvas un Polijas arhīvu avoti būtībā labi atreferē sapulces gaitu. Saskaṇā ar tiem sapulcē Lietuvas pārstāvji centās panākt, lai tiktu parakstīts kopīgs aicinājums Antantei, kas piespiestu poḷus atstāt Viḷnu (tā kā šo pilsētu un apgabalu okupējuši poḷi un pret tiem ir apvienoti ievērojami lietuviešu spēki, tos nevarot izmantot cīnā pret kopīgiem ienaidniekiem Padomju Krieviju un Vāciju). Tam pilnīgi nepiekrita Igaunijas un Latvijas armiju virspavēlnieki J. Laidoners un J. Balodis, aizbildinādamies ar pilnvaru trūkumu. J. Balodis 
nepiekrita lietuviešu piedāvājumam un izteica bažas, ka, pieņemot šādu aicinājumu, Baltijā var izveidoties tāds stāvoklis, kāds ir Balkānos (acīmredzot domāti Balkānu valstu savstarpējie bruṇotie konflikti jau kopš Balkānu kariem pirms Pirmā pasaules kara). Viņš uzskatijja, ka pat Lietuvas, Latvijas un Igaunijas apvienotie spēki nespētu tikt galā ar Polijas armiju. Tādējādi apspriede beigusies neveiksmīgi. ${ }^{10}$ Principā tas bija pareizi, kaut arī atspoguḷo galvenokārt lietuviešu redzējumu.

Toreizējais Lietuvas pārstāvis F. Krozjers vēlāk atcerējās, ka devies cauri Rīgai uz Valku un pēc tam Tallinu piedalīties sarunās pēc Lietuvas armijas virspavēlnieka prasības un ka Valkā sarunas notikušas l,oti lepnā, it kā reiz caram piederējušā salonvagonā. Par salonvagonu teiktais varētu būt patiesība, taču brīvā stilā ieturētajām un ar ievērojamu laika nobīdi rakstītajām Krozjera atmiñām raksturīgs pārspīlējums - tas atteicas uz kādreizējo piederību caram, jādomā, tāpat kā teiktais, ka sarunās Valkā piedalījušies poḷi (acīmredzot atminu autors bijis klāt citās sarunās ar poliem, tāpēc raksta, ka arī Valkā poḷi un lietuvieši "pāri galdam spḷāvuši viens otram virsū kā kaķi”). Taču viņš pamatoti atzīmē, ka sarunas beigušās faktiski bez rezultāta. ${ }^{11}$ Tiesa, patiesībā Lietuvas pārstāvji vismaz šajā reizē no Valkas devās nevis taisni uz Tallinu, bet kopā ar Latvijas pārstāvjiem 7. janvārī atgriezās Rīgā. ${ }^{12}$

5. janvāra vakarā armijas virspavēlnieks J. Balodis kopā ar vairākiem Armijas virspavēlnieka štāba virsniekiem (pulkvedi Eduardu Kalniņu u. c.), ${ }^{13}$ ar Markusu Gailīti, kuru valdība tieši šajā dienā oficiāli bija iecēlusi par diplomātisko pārstāvi Igaunijā un kurš bija tieši piedalījies konflikta risināšanā Valkā jau 2. janvārī, ar vēl sešiem Lietuvas pārstāvjiem (starp lietuviešu virsniekiem bija arī Lietuvas Ārlietu ministrijas Politiskās daḷas priekšnieks Dovs Zauṇus (Dovas Zaunius)) un vienu Lielbritānijas Militārās misijas locekli vilcienā no Rīgas devās uz Valku.
(Sarunu idejas autors - vēl amatā esošais britu Militārās misijas vadītājs A. Bērts šajās pašās dienās apmeklēja tikko atbrīvoto Daugavpili, uz turieni no Rīgas viņš izbrauca 6. janvārī.) Turklāt prese atzīmēja, ka brauciena mērḳis ir atrisināt pieminēto latviešu un igauṇu komandantūru konfliktu Valkā, tas acīmredzot daḷēji bija aizsegs brauciena galvenajam mērkịm - virspavēlniecību pārstāvju sarunām - vai katrā ziṇā bija viens no diviem uzdevumiem, jo Valkā notika arī sarunas par latviešu un igaunu konfliktu (tieši tāpēc delegācijā bija arī M. Gailītis). Arī prese, rakstot par delegācijas atgriešanos Rīgā 7. janvāra rītā, atzīmēja vienīgi faktu, ka Valkā vestas sarunas par Latvijas un Igaunijas attiecību noregulēšanu ar igaunu armijas virspavēlnieku J. Laidoneru un jauniecelto Lielbritānijas Militārās misijas Baltijas valstīs vadītāju brigādes gènerāli Arturu Tērneru (Arthur Turner), kuri atbraukuši no Tallinas. Sarunas bijušas sekmīgas, un panākta vienošanās par tālākām sarunām robežjautājumā un attiecību galīgu noregulēšanu. ${ }^{14}$ Tã tiešām bija, un minētais redzams arī šeit publicētajā dokumentā J. Laidoners virspavēlnieku sapulcē teicis, ka Igaunija "nekad neizmantos ieroču spēku", lai risinātu strīdu ar Latviju.

Kopumā sarunu dalībnieki acīmredzot ievēroja vienošanos par klusēšanu (jādomā, galvenokārt tādēḷ, ka to bija lūguši vai prasījuši igauņi, kas tikko bija noslēguši pamieru ar Padomju Krieviju un uzsākuši miera sarunas Tartu), jo presē parādījās vienīgi vispārīga informācija, ka Latvijas delegācija izbraukusi, lai tiktos ar Igaunijas armijas virspavēlnieku J. Laidoneru un A. Tērneru un apspriestu "dažus militārus, kā arī robežu jautājumus”. Pēc atgriešanās J. Balodis presei sniedzis tikpat vispārīga rakstura informāciju par sarunās panākto vienošanos ar igauniem, ka Valkas konflikts tiks atrisināts savstarpējās sarunās. ${ }^{15}$ Savukārt Lietuvas pārstāvis A. Merḳis pēc atgriešanās Rīgā sarunā ar vietējā krievu 
laikraksta "Segodņa" korespondentu A. Gorevu bija daudz atklātāks - izklāstījis savas valdības nostāju pret Poliju, viņš izstāstīja arī par braucienu uz Valku un pieminēja piedalīšanos " $p \bar{e} c$ anglu iniciativas sasauktajā Latvijas, Lietuvas un Igaunijas virspavēlnieku konference $\bar{e} .{ }^{16}$

Pēc britu iniciatīvas Valkā notikušās Baltijas valstu armiju virspavēlniecības sarunas neapšaubāmi ir būtiskas reǵiona vēsturē. Faktiski tās bija vienīgās šãda līmeṇa sarunas ar visu triju valstu armiju vadỉbas piedalīšanos, turklāt publicētajā dokumentā fiksētais rezultāts labi demonstrē iemeslus, kas neḷāva Baltijas valstīm noslēgt militāru konvenciju ne 1920., ne vēlākajos gados, kā arī aktuālo situāciju 1920. gada sākumā. Vispirms tika konstatēts, ka visas trīs valstis, kaut arī atšķirīgā intensitātē, par ienaidniekiem uzskata Vāciju un Padomju Krieviju (šajā laikā tieši Latvija acīmredzot pēc smagajām kaujām faktiski vienatnē pret Bermonta armiju atzina Vāciju par lielāko draudu, savukārt Lietuva Padomju Krieviju uzskatīja par mazāko no draudiem), taču Lietuva savu galveno apdraudējumu saskatīja Polijā. Visu triju valstu armiju vadība uzsvēra vienotības un sabiedroto atbalsta nepieciešamību, taču latvieši un igauṇi atklāti atteicās sniegt atbalstu Lietuvai pret Poliju, bet lietuvieši pārmeta latviešiem, ka viņi atñēmuši tiem politiski nepieciešamo frontes sektoru pret Sarkano armiju. Rezultātā pēc apmaiṇas ar domām par iespējamo bruṇojumu un resursiem, ar ko puses varētu dalīties savstarpēji (faktiski bija runa par otrškirīīām un nelielām lietām), tika pieņemta kopēja rezolūcija par sadarbības nepieciešamību, vēršoties pie sabiedrotajiem palīdzēt atrisināt l̦oti traucējošo Lietuvas un Polijas robežstrīdu jeb konfliktu.

Britu Militārās misijas pārstāvji sarunās, kuras faktiski bija iniciējuši, paši nepiedalījās (neskaitot ǵ generāli F. Krozjeru, kurš oficiāli bija Lietuvas delegācijas sastāvā, un arī minētais liecina par britu interesēm reǵionā kopumā aplūkojamajā laikā), taču vērīgi tām sekoja, un nevar izslēgt, ka neoficiāli bija tajās klātesoši. Lielbritānijas misijas arī turpmāk saglabāja iniciatīvu, veicinot Baltijas valstu savstarpējo saprašanos robežu jautājumos.

\section{Document}

172375 Jan 231920

Military Conference held at Walk 11 a. m. $6^{\text {th }}$ January 1920

Present:

General LAIDONER (Presiding), Estonian C.[commander] in C.[hief]

Colonel BALLOD, Latvian C. in C.

Colonel KALNIN, Latvia.

Colonel MERKIS, Lithuanian Dep., C. in C.

Colonel KLESCHINSKY, Lithuanian General Staff.

General CROZIER, Lithuania.

\section{FIRST SITTING.}

The first question put by General LAIDONER to the meeting was:

What did the representatives of the three Baltic States consider to be the principal menace to their respective countries? 
ESTONIA has two enemies:

(a) A Bolshevik Russia or a United Russia that will not recognise Estonia's independence.

(b) Germany and their advance guard - the united nobility (Barons).

A union of Baltic States and good relations with the Allies is the best support against German Imperialism.

LATVIA - the same, only Germany is more dangerous and Courland is threatened. The Germans under BISHOFF are concentrating near MEML and LATVIAN territory is still occupied by Bolsheviks.

LITHUANIA considers the Poles her worst enemy. The capital of Lithuania and a great part of her territory is occupied by them. The Bolsheviks are not so dangerous to them as they are to LATVIA or ESTONIA. The Germans are likely to attack LITHUANIA first. A great deal of Bolshevik propaganda is being spread by the Germans. The Lithuanians complain that they have no allies against the Poles and they are not strong enough to drive them out themselves.

Colonel BALLOD. LATVIA cannot help. Action would lead to the creation of a "BALKAN" situation. Other ways must be found to deal with this question.

General LAIDONER. In these days the policy of States is decided by the people and not by Governments. The Estonian people neither feel one way nor the other in this question.

Colonel CROZIER. Suggest that Allied representatives in the Baltic should be petitioned.

The second question raised by General LAIDONER was:

How to deal with enemies?

The LITHUANIANS stated that they are concentrating against the Poles, but would prefer moral support of the Baltic States and Allies. If this fails, they will fight.

The Lithuanians are prepared to join the Baltic States in any step taken by them against Germany.

For political and military reasons, the Lithuanians must keep in touch with the Bolshevik front. Even outside Lithuanian territory. Their main object in this question is to have a right to claim compensation, territorial rights and Allied material.

General LAIDONER. What forces, material, moral, \& c. would be at the disposal of each State in every respective instance?

Colonel KLESCHINSKY. If all negotiations fail with Poland only force remains. Every man will be put into the field and will fight, but Poles are stronger than the three combined Baltic States. In the case of Germany, the army depends on the material given by Allies and neighbours. 50'000 men could be raised and two divisions sent against the Bolsheviks and two against the Germans.

General LAIDONER. Do Lithuanians expect attack by Germans? 
Colonel MERKIS. Yes.

Colonel KLESCHINSKY. Lithuania cannot resist Germany long because they have no munitions. They can put two divisions into the field against the Bolsheviks. The troops will fight all three enemies (the Bolsheviks, Germans or Poles) readily.

Colonel BALLOD. Latvia's greatest enemy is Germany. One division is ready to take the field, but there are no horses for the second division. The Baltic States can always expect full support from the Allies if attacked by Germany. Latvia has two divisions fighting the Bolsheviks, but cannot fight them alone. The left flank of the army is protected, but Poland is necessary. The Landeswehr is doing good work. The offensive in LATGALIA has commenced and it will be held by force.

Colonel KLESCHINSKY remarked that the Lettish left flank is not in the air because they have the support of the Lithuanian Army, but there is no liaison between the two. The Lithuanian Army is being pushed out of the front line by the Letts, but the Lithuanians must keep touch with the Bolsheviks for political and military reasons (Terms with Bolsheviks, supplies from Allies).

General LAIDONER. Estonia will not take any action against the Bolshevik, but will resist Bolshevik attacks. The anti-Bolshevik Russians are too weak now to help. Estonia cannot last out long against the Bolshevists and it would only be a defensive war.

If GERMANY attacks again, Estonian attitude will be the same as before. They will not be able to move at once because threatened by Bolsheviks. Only if Riga is taken and the Germans come East of DVINA will the Estonians take action on their own initiative. Otherwise, a military convention with Latvia is necessary. In that case, one division could be sent West of DVINA. The Germans are spreading great deal of Bolshevik propaganda in Estonia. Estonia will never use arms to decide internal questions with Latvia. Estonia would also be in danger is Bolsheviks entered Latvia. Must have UNITY. Cannot exist without Allied support. Munitions only enough to meet first blow.

General LAIDONER then stated that as all the representatives of the three Baltic States present held the same views and had common enemies, they could agree on the following points:

(1) Form a defensive convention against Germany.

(2) Form a defensive convention against Bolsheviks.

(3) Request the Allies to intercede and decide the question of Polish and Lithuanian frontiers.

(4) If Russia went Anti-Bolshevik but refused to recognise their independence, to form an Anti-Russian convention. FINLAND could be invited to join in (2) and (4) but cannot take part against Germany.

(5) From military point of view, it is desirable to have a railway, post and telegraph conventions.

All parties present agreed to these five points in the first sitting. 
A few minutes were then given to the question of interchange of material.

ESTONIA has no material to spare, but could offer some Russian (1877) 6-inch guns with munitions.

LITHUANIA could offer raw material (leather, wood, salt), 50 Russian waggons, 50 engines (aviation), very short of 3-inch shells. Plenty medical stores.

LATVIA has the means to convert the raw material.

The first sitting closed at 1-45 p.m.

\section{SECOND SITTING.}

The same members were present at the second sitting.

The sitting commenced by Colonel KLESHINSKY reading the first text of the resolution relating to the Polish-Lithuanian frontier question.

The text suggested in the morning contained a short request to the Allied Mission in the Baltic to undertake the settlement of the dispute, as the present situation was weakening the military potentiality of the Baltic States. It was very carefully worded. The Text as amended by Colonel KLESCHINSKY contained refences to Lithuanian territory and VILNA being "seized" by the Poles. It also contained a clause "that POLAND would not be admitted into the convention until Lithuania was satisfied".

Translation from Russian.

\section{PROTOCOL OF CONFERENCE}

Between the representatives of the General Commands of Estonia, General Laidoner; Latvia, Colonel Ballod; and Lithuania, Major Merkis, held on January 6th, 1920, in Walk.

1. All representatives of the General Command having in view the common danger from Germany, from Bolsheviks, and also from a reactionary imperialistic Russia, all endeavouring to destroy the independent existence of Estonia, Latvia and Lithuania, have come to a unanimous decision as to the immediate necessity of concluding a defensive military convention between these States in the event of threatened danger from the side of Germany or Russia.

2. Moreover, the representatives of the General Commands are aware of the immediate desirability from the military point of view of concluding railway and postaltelegraphic convention intercommunications between the respective States.

3. The representatives of the General Commands appreciate the great desirability of a settlement at the same time of all frontier questions between Estonia and Latvia, and between Latvia and Lithuania. Decision of such questions would remove such frictions and misunderstandings with regard to frontier questions, as are at present hindering the harmonious relations of the States referred to.

4. The representative of the Lithuanian General Command proposed the following resolution:

"Having heard the statement of the representative of the Lithuanian General Command respecting relations between the Lithuanians and Poles, and in view of the statement of the representative of the Lithuanian General Command that the occupation of a considerable part of Lithuanian territory, including her capital Vilna, heavily handicaps the organization of the State, decreases the available Lithuanian military forces, which might 
be utilised successfully against the common enemies of the Baltic States - the Bolsheviks and the Germans - the representatives of the General Command of Estonia, Latvia, and Lithuania have come to the unanimous decision to appeal to the Entente to use its authoritative influence towards the earliest settlement of the Lithuanian-Polish frontier question". The Estonian and Latvian Commanders-in-Chief were unable to accept this resolution, on account of not being authorised to consider such in the absence of the representative of the Polish General Command.

(Signed)

Major-General Laidoner

Colonel Ballod

Major Merkis

Correct according to original

Lieutenant Bekker

\section{Dokuments}

172375 1920. gada 23. janvārī

Militārā apspriede Valkā 1920. gada 6. janvārī plkst. 11.00

Piedalās:

G̦enerālis LAIDONERS ${ }^{17}$ (apspriedes vadītājs), Igaunijas a[rmijas] v[irspavēlnieks].

Pulkvedis BALODIS, ${ }^{18}$ Latvijas a[rmijas] v[irspavēlnieks].

Pulkvedis KALNIN̦Š, ${ }^{19}$ Latvija.

Pulkvedis ${ }^{20}$ MERĶIS, ${ }^{21}$ Lietuvas pārst[āvis], a[rmijas] v[irspavēlnieks]. ${ }^{22}$

Pulkvedis KLEŠČINSKS, ${ }^{23}$ Lietuvas G̦enerālštābs.

Ģenerālis KROZJERS ${ }^{24}$ Lietuva.

PIRMĀ SĒDE.

Pirmais jautājums, ko ǵenerālis LAIDONERS izvirzijja apspriešanai, bija:

Ko triju Baltijas valstu pārstāvji uzskatīja par galveno apdraudējumu savām valstīm?

IGAUNIJAI ir divi ienaidnieki:

(a) Boḷševiku Krievija vai apvienota Krievija, kas neatzīs Igaunijas neatkarību.

(b) Vācija un tās avangards - apvienotā muižniecība (baroni).

Baltijas valstu savienība un labas attiecības ar sabiedrotajiem ir labākais veids, kā cīnīties ar vācu imperiālismu.

LATVIJA - tas pats, vienīgi Vācija ir bīstamāka un apdraud Kurzemi. Vācu spēki BIŠOFA vadībā tiek koncentrēti KLAIPĒDĀ, un Latvijas teritoriju joprojām ir pārṇēmuši boḷševiki.

LIETUVA uzskata, ka tās galvenais ienaidnieks ir poḷi. Viṇi ir pārṇēmuši Lietuvas galvaspilsētu un lielu daḷu tās teritorijas. Boḷševiki tai nav tik bīstami kā LATVIJAI vai IGAUNIJAI. 
Ticams, ka vācieši vispirms uzbruks LIETUVAI. Ievērojamu daḷu no bolševiku propagandas izplata vācieši. Lietuvieši pauž nožēlu, ka viniem nav sabiedroto pret poḷiem un ka vinịi nav pietiekami spēcīgi, lai aizdzìtu tos paši.

Pulkvedis BALODIS. LATVIJA nevar palīdzēt. Tāda akcija var novest pie "BALKĀNU" situācijas izveidošanās. Jāatrod citi ceḷi, kā risināt šo jautājumu.

Ģenerālis LAIDONERS. Šajā laikā valstu politiku nosaka tautas, nevis valdības. Igauṇu tautai šajā jautājumā nav noteiktas nostājas.

Pulkvedis KROZJERS. Piedāvā vērsties pie sabiedroto pārstāvjiem Baltijas valstīs ar iesniegumu.

Otrs jautājums, ko izvirzīja genenerālis LAIDONERS, bija:

Kā izturēties pret ienaidniekiem?

LIETUVIEŠI paziņoja, ka viņi koncentrē spēkus pret poḷiem, taču vēlas saņemt morālu atbalstu no Baltijas valstīm un sabiedrotajiem. Ja tas netiks saṇemts, vini cīnīsies.

Lietuvieši ir gatavi pievienoties Baltijas valstīm jebkurā darbībā, ko tās vērsīs pret Vāciju. Politisku un militāru iemeslu dēḷ lietuviešiem jāsaglabā saikne ar boḷševiku fronti. Pat ārpus Lietuvas teritorijas. Viṇu galvenais mērḳis šajā lietā ir iegūt tiesības prasīt kompensāciju, izvirzìt teritoriālas prasības un saṇemt [kara] materiālu atbalstu no sabiedrotajiem.

G̦enerālis LAIDONERS. Kādi spēki, materiāli, stimuli u. c. ir katras valsts rīcībā katrā konkrētā gadījumā?

Pulkvedis KLEŠČINSKS. Ja visas sarunas ar Poliju beigsies nesekmīgi, atliks vienīgi spēks. Visi vīri līdz pēdējam tiks sūtīti kaujā un cīnīsies, taču poḷi ir spēcīgāki par trīs Baltijas valstīm kopā. Runājot par Vāciju, armija ir atkarīga no kara materiāliem, ko dod sabiedrotie un kaimiņi. Ir iespējams mobilizēt 50000 vīrus un sūtīt divas divīzijas pret boḷ̌ševikiem un divas pret vāciešiem.

Ģenerālis LAIDONERS. Vai lietuvieši sagaida vāciešu uzbrukumu?

Pulkvedis MERḲIS. Jā.

Pulkvedis KLEŠČINSKS. Lietuvieši nevar ilgi pretoties vāciešiem, jo viṇiem trūkst munīcijas. Viṇi ir nosūtījuši divas divizijas cīṇā pret boḷ̌̌evikiem. Karaspēks būs gatavs cīnīties ar visiem trim ienaidniekiem (boḷševiki, vācieši vai poḷi).

Pulkvedis BALODIS. Latvijas lielākais ienaidnieks ir Vācija. Viena divīzija ir gatava doties cīnā, taču otrai divīzijai trūkst zirgu. Baltijas valstis vienmēr var sagaidīt pilnu atbalstu no sabiedrotajiem Vācijas uzbrukuma gadījumā. Latvijai ir divas divīzijas, kuras cīnās ar boḷševikiem, taču tā nevar cīnīties ar viniem viena. Kreisais ${ }^{25}$ armijas spārns ir aizsargāts, taču tam ir nepieciešama Polija. Landesvērs dod lielu atbalstu. Uzbrukums LATGALĒ ir uzsākts un tiks turpināts. 
Pulkvedis KLEŠČINSKS atzīmēja, ka latviešu kreisais spārns nav nenosegts, jo tiem ir nodrošināts Lietuvas armijas atbalsts, taču starp abiem nepastāv nekādi sakari. Latvieši atspiež Lietuvas armiju no frontes līnijas, taču lietuviešiem jāsaglabā saikne ar boḷševikiem politisku un militāru iemeslu dēḷ (sarunas ar boḷ̌švikiem, piegādes no sabiedrotajiem).

G̦enerālis LAIDONERS. Igaunija neuzsāks nekādas darbības pret boḷševikiem, taču pretosies boḷševiku uzbrukumiem. Pretboḷševistiskie krievi pašlaik ir pārāk vāji, lai palīdzētu. Igaunija nevar ilgi noturēties pret boḷševikiem, un tas būtu vienīgi aizstāvēšanās karš.

Ja VĀCIJA atkal uzbruks, Igaunijas attieksme būs tāda pati kā iepriekš. Igauṇi nevarēs uzreiz sākt darbību bolšseviku apdraudējuma dēḷ. Vienīgi tad, ja kritīs Rīga un vācieši pārnāks uz DAUGAVAS austrumu krastu, igauṇi iesaistīsies pēc pašu iniciatīvas. Pretējā gadījumā ir nepieciešams militārs līgums ar Latviju. Tad vienu divīziju var nosūtīt uz DAUGAVAS rietumu krastu. Vācieši bagātīgi izplata Igaunijā boḷ̌seviku propagandu. Igaunija nekad neizmantos ieročus, lai risinātu iekšêjās lietas ar Latviju. Arī Igaunija tiks apdraudēta, ja boḷševiki ienāks Latvijā. Jāpanāk VIENOTĪBA. [Igaunija] nevar pastāvēt bez sabiedroto atbalsta. Munīcijas pietiek vienīgi pirmā trieciena atvairī̌̌anai.

Tad generālis LAIDONERS paziņoja: tā kā visu triju Baltijas valstu klātesošajiem pārstāvjiem ir vienādi uzskati un kopīgi ienaidnieki, tie var vienoties par sekojošiem punktiem:

(1) Izveidot aizsardzības savienību pret Vāciju.

(2) Izveidot aizsardzības savienību pret boḷševikiem.

(3) Lūgt sabiedrotos būt par starpnieku un izšķirt Polijas un Lietuvas robežas jautājumu.

(4) Ja Krievija kḷūtu antiboḷševistiska, taču atteiktos atzìt Baltijas valstu neatkarību, izveidot pretkrievu savienību. Var uzaicināt SOMIJU pievienoties (2) un (4) punktā [minētajām savienībām], taču tā nevar piedalīties [savienībā] pret Vāciju.

(5) No militārā viedokḷa vēlams, lai būtu [savstarpēji] dzelzceḷa, pasta un telegrāfa līgumi.

Visas klātesošās puses pirmajā sēdē piekrita šiem pieciem punktiem.

Pēc tam vairākas minūtes tika apspriests jautājums par [kara] materiālu apmainu.

IGAUNIJAI nav brīvu materiālu, taču tā var piedāvāt dažus krievu (1877. gada) 6 collu lielgabalus ar munīciju.

LIETUVA var piedāvāt jēlmateriālus (ādas, vilnu, sāli), 50 krievu vagonus, 50 motorus (aviācijas), l,oti nedaudz 3 collīgo šāviņu. Liels daudzums medicīnas preču krājumu.

LATVIJAI ir iespējas pārstrādāt ${ }^{26}$ jēlmateriālus.

Pirmā sēde noslēdzās plkst. 1.45 pēcpusdienā.

\section{OTRĀ SĒDE.}

Otrajā sēdē piedalījās tie paši pārstāvji.

Sēdi atklāja pulkvedis KLEŠČINSKS, nolasīdams pirmo rezolūcijas tekstu par Polijas un Lietuvas robežas jautājumu.

No rīta piedāvātais teksts ietvēra īsu prasību sabiedroto misijām Baltijā uzṇemties atrisināt strīdu, jo pašreizējā situācija vājina Baltijas valstu militārās spējas. Teksts bija veidots, loti uzmanīgi izvēloties vārdus. Pulkveža KLEŠČINSKA papildinātais teksts ietvēra atsauces uz 
poḷu "sagrābto" Lietuvas teritoriju un VIL,N̦U. Tajā bija arī sacīts, "ka POLIJA nevar tikt iekḷauta savienībā, kamēr Lietuva nav apmierināta [ar situāciju]”.

Tulkojums no krievu valodas.

KONFERENCES PROTOKOLS

[Konference] [s]tarp virspavēlniecību pārstāvjiem no Igaunijas, [pārstāv] ǵenerālis Laidoners, no Latvijas, [pārstāv] pulkvedis Balodis, un no Lietuvas, [pārstāv] majors Merḳis, notika Valkā 1920. gada 6. janvārī.

1. Visi virspavēlniecību pārstāvji, ievērojot kopējo apdraudējumu no Vācijas, no boḷševikiem un no reakcionārās imperiālistiskās Krievijas, kas cenšas iznīcināt Igaunijas, Latvijas un Lietuvas neatkarīgu pastāvēšanu, ir nonākuši pie vienprātīga lēmuma par nepieciešamību noslēgt militāru aizsardzības savienību starp šìm valstīm gadījumam, ja draudētu briesmas no Vācijas vai Krievijas.

2. Turklāt virspavēlniecību pārstāvji apzinās nepieciešamību no militārā viedokḷa noslēgt dzelzceḷa un pasta-telegrāfa konvenciju satiksmei un sakariem starp attiecīgajām valstìm.

3. Virspavēlniecību pārstāvji tajā pašā laikā izprot, ka ārkārtīgi nepieciešams nokārtot visus robežu jautājumus starp Igauniju un Latviju un starp Latviju un Lietuvu. Šãdu jautājumu izšḳiršana novērstu tās nesaskaņas un pārpratumus par robežu jautājumiem, kas šajā laikā kavē saskaņotām attiecībām starp minētajām valstīm.

4. Lietuvas virspavēlniecības pārstāvis piedāvāja pieṇemt šādu rezolūciju:

“Noklausījušies Lietuvas virspavēlniecības pārstāvja paziņojumu par attiecībām starp lietuviešiem un poḷiem un ievērojot Lietuvas virspavēlniecības pārstāvja sacīto, ka plašas Lietuvas teritorijas daḷas, ieskaitot tās galvaspilsētu Viļ̣u, okupācija ievērojami traucē valsts vadīšanu un samazina pieejamo Lietuvas karaspēku, ko varētu sekmīgi izmantot pret Baltijas valstu kopīgajiem ienaidniekiem - boḷševikiem un vāciešiem -, Igaunijas, Latvijas un Lietuvas virspavēlniecību pārstāvji ir nonākuši pie vienprātīga lēmuma lūgt Antanti izmantot tās autoritatīvo ietekmi, lai iespējami ātri atrisinātu lietuviešu-poḷu robežas jautājumu."

Igauṇu un latviešu virspavēlnieki nevarēja pieņemt šo rezolūciju, nebūdami pilnvaroti tādu apspriest bez poḷu virspavēlniecības pārstāvja klātbūtnes.

(Paraksti)

G̦enerālmajors Laidoners

Pulkvedis Balodis

Majors Merkis

Pareizi saskaṇā ar oriǵninālu

Leitnants Bekers ${ }^{27}$

Avots: National Archives of United Kingdom, Foreign Office, 371/3619, 406-412. 


\section{ATSAUCES UN SKAIDROJUMI}

${ }^{1}$ Publikācija sagatavota ar Lietuvas Zinātnes padomes projekta S-MIP-21-46 atbalstu.

${ }^{2}$ Sīkāk sk.: ĒRIKS JĒKABSONS. Piesardzīgā draudzība: Latvijas un Polijas attiecības 1919. un 1920. gadā. Rīga 2007, 67.-68. lpp.

${ }^{3}$ Sīkāk sk.: ĒRIKS JĒKABSONS. Lietuvas karaspēks Ilūkstes apriņưi 1919.-1920. gadā. In: Latvijas Zinātṇu Akadēmijas Vēstis. A daḷa. Sociālās un humanitārās zinātnes 59, 2005, Nr. 2, 49.-64. lpp.

${ }^{4}$ Sk., piemēram: Valkas apriņķa komandanta vietas izpildītāja Teodora Birnbauma 1920.02.01. ziņojums, 01.02.1920. Latvijas Nacionālā arhīva Latvijas Valsts vēstures arhīvs, Rīga (turpmāk LNA LVVA), 3601-1-272, 119.-120. 1p. u. c.

${ }^{5}$ Sk., piemēram, toreizējā Latvijas armijas virspavēlnieka J. Baloža liecību: JĀNIS BALODIs. Atmiņu burtnīcas. 1918.-1939. gads. Publ. sagatavojis Andris Caune. Rìga 2015, 179. lpp.

${ }^{6}$ Sk.: ĒRIKS JĒKABSONS, KLĀVS ZARIN̦Š. Lielbritānijas Baltijas politikas galvenie virzieni un pārstāvji Latvijā 1918.-1920. gadā: ieskats darbībā. In: ĒRIKS JĒKABSONS, KLĀVs ZARIN̦Š (sast.). Latvijas Neatkarības karš 1918.-1919. gadā: Lielbritānijas kara flotes ziṇojumi. Latvian War of Independence 1918-1919: Reports of British Royal Navy. Rīga 2019, 7.-64. lpp.

7 LNA LVVA, 3601-1-269, 255. lp.

${ }^{8}$ EDGARS ANDERSONS. Latvijas vēsture 1914-1920. Stockholm 1967, 564. lpp.

${ }^{9}$ KĀRLIS Počs. Sanitārā kordona valgos. Baltijas savienības jautājums buržuāziskās Latvijas ārpolitikā 1919.-1925. gadā. Rīga 1971, 62. lpp.

${ }^{10}$ Lietuvos Centrynis valstybinis archyvas, Viḷna (Lietuvas Centrālais valsts arhīvs), 384-3-14, 11.15. lp.; Archiwum Akt Nowych, Sztab Główny, Varšava, t. 616/5, k. 58.

${ }^{11}$ FrANK Percy Crozier. Impressions and Recollections. London 1930, p. 245.

${ }^{12} \mathrm{U}$ tov. ministra oborony Litvy. In: Segodnia, 18.01.1920., 1. s.

${ }^{13}$ Valkas sarunas savās atmin̄ās nemin ne J. Balodis, ne E. Kalniņš.

${ }^{14}$ Mūsu komendantūras attiecības ar igauniem Valkā. In: Jaunākās Ziṇas, 07.01.1920., 7. lpp.; Mūsu attiecību nokārtošana ar Igauniju. In: Jaunākās Ziṇas, 08.01.1920., 7. lpp.

${ }^{15}$ Uz Valku. In: Latvijas Sargs, 06.01.1920., 1. lpp.; Latvijas un Igaunijas konflikta lietā. In: Latvijas Sargs, 08.01.1920., 1. lpp.

${ }^{16} \mathrm{U}$ tov. ministra oborony Litvy.

${ }^{17}$ Johans Laidoners (Johan Laidoner, 1884-1953). Igaunijas armijas generālmajors, no 1920. gada marta - ǵenerālleitnants. 1918.-1921. gadā armijas virspavēlnieks. Miris padomju ieslodzījumā.

18 Jānis Balodis (1881-1965), Latvijas armijas pulkvedis, no 1920. gada 23. janvāra generālis. 1919.-1921. gadā armijas virspavēlnieks. Miris pēc atbrīvošanas no padomju ieslodzījuma.

${ }^{19}$ Eduards Kalniņš (1876-1964), Latvijas armijas pulkvedis, no 1925. gada generālis. No 1919. gada oktobra Galvenās artilērijas pārvaldes priekšnieks. Miris trimdā ASV.

${ }^{20}$ İstenībā A. Merḳis šajā laikā bija kapteinis.

${ }^{21}$ Antans Merkis (Antanas Merkys, 1887-1955), Lietuvas jurists, valstsvīrs, virsnieks. No 1919. gada 7. oktobra apsardzības ministrs un armijas virspavēlnieka vecākais palīgs. Kapteinis, no 1920. gada 3. februāra majors, no 1922. gada pulkvežleitnants. 1939.-1940. gadā Ministru prezidents. Miris pēc atbrīvošanas no padomju ieslodzījuma.

${ }^{22}$ İstenībā - apsardzības ministrs un armijas virspavēlnieka palīgs.

${ }^{23}$ Konstantins Kleščinsks (Konstantinas Kleščinskas, 1879-1927), Lietuvas armijas pulkvedis, vēlāk generālleitnants. No 1919. gada novembra G̦enerālštāba priekšnieka palīgs. 1923. gadā atvalināts, 1927. gadā arestēts kā PSRS aǵents no 1924. gada, sodīts ar nāvi.

${ }^{24}$ Frenks Persijs Krozjers (Frank Percy Crozier, 1879-1937), Lielbritānijas armijas brigādes geneneālis. No 1919. gada 19. septembra lìdz 1920. gada 1. martam Lietuvas armijas padomnieks, iekḷauts Lietuvas armijas sastāvā, ǵenerālmajors.

${ }^{25}$ Acīmredzot domāts Latvijas armijas labais spārns. 
${ }^{26}$ Iespējams, ar vārdu convert domāts, ka Latvija var piešḳirt kaimiṇvalstīm jēlmateriālus.

${ }^{27}$ Iespējams, Alfrēds Herberts Bek̦eris (1896-1936), Latvijas armijas virsleitnants, vēlāk kapteinis. No 1919. gada jūlija dienēja Armijas virspavēlnieka štāba Operatīvās daḷas Operatīvajā nodaḷā, no 1920. gada 1. janvāra vecākais sevišķu uzdevumu virsnieks. Šajā gadījumā varētu būt runa par protokola tehnisku sagatavošanu, ko veica A. Bekeris. Acīmredzot vinš 6 . janvārī piedalījās sarunās kā to protokolētājs vai arī vienīgi tulkoja dokumentu angḷu valodā (līdz šim LNA LVVA krājumos to nav izdevies atrast); 23. janvārī Rīgā, darbu noslēdzot, sagatavoja Lielbritānijas misijai nosūtāmo dokumentu, kas šeit publicēts. 